\title{
13. QUANTITATIVE DISTRIBUTION PATTERNS OF SELECTED LOWER TO MIDDLE MIOCENE CALCAREOUS NANNOFOSSILS FROM THE ONTONG JAVA PLATEAU
}

\author{
Eliana Fornaciari, ${ }^{2}$ Jan Backman, ${ }^{3}$ and Domenico Rio ${ }^{2}$
}

\begin{abstract}
Uppermost Oligocene through middle Miocene calcareous nannofossil events that were considered potentially useful from a biostratigraphic point of view have been investigated from Ocean Drilling Program Sites 806 and 807 in the western equatorial Pacific Ocean. Comparisons have been made to the corresponding events from other equatorial regions and the mid-latitude North Atlantic. In terms of biostratigraphic reliability, defined by the ability of the pertinent species to provide distinctive marker events and synchroneity over geographic distance, the investigated events can be classified into four general categories:

The good markers: last occurrence (LO) Sphenolithus ciperoensis, first occurrence (FO) S. delphix, LO S. delphix, FO S. belemnos, LO S. belemnos, FO S. heteromorphus, termination acme (TA) Discoaster deflandrei, and LO Sphenolithus heteromorphus.

The poor markers: LO Helicosphaera recta, TA Cyclicargolithus abisectus, LO Triquetrorhabdulus carinatus, and FO Calcidiscus macintyrei.

Ecologically controlled markers with regional value: LO Dictyococcites bisectus, LO Helicosphaera ampliaperta, FO Reticulofenestra pseudoumbilica, LO Cyclicargolithus floridanus, and LO Coronocyclus nitescens.

The low abundance markers: FO Discoaster druggii, gradational form of Sphenoliths dissimilis/Sphenolithus belemnos, FO Triquetrorhabdulus rugosus, and FO T. rioensis.
\end{abstract}

\section{INTRODUCTION}

Recent work by Olafsson (1989, 1991), Rio et al. (1990), and Fornaciari et al. (1990) indicates that potential still exists for improving the resolution of Miocene calcareous nannofossil biostratigraphy, which is low when compared with the Pliocene and Pleistocene. We anticipate that the resolution of Miocene biochronology can be improved. In a recent study from the equatorial Indian Ocean, we adopted a quantitative approach and showed that there are several marker events available other than those normally used in the widely adopted zonations of Martini (1971) and Okada and Bukry (1980), and which are biostratigraphically valuable. Extended Miocene sections from the Ontong Java Plateau in the western equatorial Pacific Ocean were recovered during Ocean Drilling Program (ODP) Leg 130. These sections provide a good opportunity to test the biostratigraphic utility of several biostratigraphic events. In this paper we show quantitative distribution patterns of selected calcareous nannofossils to establish precisely the stratigraphic positions of events, and to expand the existing quantitative data base that can be used to interpret the character and reliability of these events in different geographic regions. We compare our results from the Ontong Java sections with contemporaneous sections from the equatorial Indian Ocean and the mid-latitude North Atlantic.

\section{MATERIAL AND METHODS}

The Ontong Java Plateau data is derived from two sequences, namely, the intermediate-deep Hole 806B $(2520 \mathrm{~m})$ and Hole $807 \mathrm{~A}$ $(2804 \mathrm{~m})$. Hole $806 \mathrm{~B}$ is $35 \mathrm{~km}$ north of the equator, whereas Hole $807 \mathrm{~A}$ is about $400 \mathrm{~km}$ north of the equator. Details of these sedimentary sequences about the physiographic setting of the sites, core recovery rates, lithologies, and general stratigraphic properties, are presented in Kroenke, Berger, Janecek, et al. (1991). We also present

'Berger, W.H., Kroenke, L.W., Mayer, L.A., et al., 1993. Proc. ODP, Sci. Results, 130 College Station, TX (Ocean Drilling Program).

${ }^{2}$ Dipartimento di Geologia, Paleontologia e Geofisica, Università di Padova, via Giotto 1, 35137 Padova, Italy.

${ }^{3}$ Department of Geology and Geochemistry, Stockholm University, S-106 91 Stockholm, Sweden. data concerning the evolution of the lower and middle Miocene Sphenolithus lineage from Indian Ocean Holes 709C and 710A. Site 709 was drilled at $3^{\circ} 55^{\prime} \mathrm{S}$ and $60^{\circ} 33^{\prime} \mathrm{E}$ at a water depth of $3041 \mathrm{~m}$, whereas Site 710 was drilled at $04^{\circ} 19^{\prime} \mathrm{S}$ and $60^{\circ} 59^{\prime} \mathrm{E}$ at a water depth of $3824 \mathrm{~m}$ (Backman, Duncan, et al. (1988).

Smear slides were prepared following standard techniques (see, e.g., Backman, Duncan, et al., 1988, "Explanatory Notes" chapter). Quantitative data were collected with the light microscope according to three methods: (1) counting the index species relative to the total assemblage; (2) counting $D$. deflandrei relative to all discoasters; and (3) counting the number of specimens of the index species per unit area of the slide.

Backman and Shackleton (1983) and Rio et al. (1989) have discussed these three methods at length, indicating their respective advantages as well as their limits of applicability. For comparative purposes, we have in some cases applied two of these methods for the same event. The taxonomic concepts used in this study are discussed in Rio et al. (1990) and Fornaciari et al. (1990).

\section{BIOSTRATIGRAPHY}

\section{Events Across the Oligocene/Miocene Boundary and the NP25 Problem}

Many calcareous nannofossil biostratigraphers place the Oligocene/Miocene boundary at the top of Martini's (1971) Zone NP25. Martini defined the NP25/NN1 zonal boundary by the LO of Helicosphaera recta. This species is easy to recognize but it is rarely present in open-ocean areas. The fact that $H$. recta is absent in a large portion of oceanic Oligocene/Miocene boundary sections has tempted many biostratigraphers to find suitable replacements for $H$. recta to approximate the position of the NP25/NN1 boundary.

Bukry (1975) modified his original zonation from 1973 and established the Dictyococcites bisectus Subzone, the top of which was defined by the LO of Sphenolithus ciperoensis. Okada and Bukry (1980) subsequently assigned the code number $\mathrm{CP} 19 \mathrm{~b}$ for that subzone. The LO of $S$. ciperoensis is the most widely used alternative criterion which have been used for the top of Zone NP25 (e.g., Berggren et al., 1985a). Bukry (1973, 1975) also suggested that the LO of Dictyococcites bisectus can be used as an auxiliary marker to recognize the top of the $D$. bisectus Subzone (Subzone CP19b in Okada and Bukry's terminology). Fi- 
nally, the LO of Clausicoccus fenestratus also has been proposed to approximate the top of Zone NP25 (Bizon and Müller, 1979), although this event has been rarely used.

We have quantitatively determined the distribution of all these taxa in Hole $807 \mathrm{~A}$, where a relatively complete section was recovered across the Oligocene/Miocene boundary interval (Fig. 1). Helicosphaera recta and $D$. bisectus are missing in the upper Oligocene sediments investigated from the Ontong Java Plateau sites. The range of $C$. fenestratus apparently continues well above the LO of $S$. ciperoensis (Table 1 and Fig. 1). In the equatorial Indian Ocean, we observed that $D$. bisectus became extinct together with $S$. ciperoensis (Rio et al., 1990; Fornaciari et al., 1990). Available data from mid-latitude regions suggest that $D$. bisectus survived $S$. ciperoensis for an interval of time in excess of 1 m.y. (Miller et al., 1985; Wei and Wise, 1989; Olafsson, 1991). Paleomagnetic reversal data are not available from Hole $807 \mathrm{~A}$, but because the LO of $S$. ciperoensis is virtually synchronous between low- and mid-latitude regions (Olafsson, 1991), it may be surmised that the absence of $D$. bisectus in the vicinity of the extinction level of $S$. ciperoensis at Site 807 must reflect the fact that $D$. bisectus disappeared significantly earlier from the low-latitude setting of the Ontong Java Plateau than from mid-latitude regions.

In the equatorial Indian Ocean, $H$. recta was observed in lower Miocene sediments at ODP Sites 714 and 715 . Oligocene sediments are not reworked into the lower Miocene portion at Site 714 (Rio et al., 1990). The occurrence of $H$. recta above the FO of Discoaster druggii in this site (Fig. 2), that is, above the base of Zone NN2, therefore implies an indigenous presence of $H$. recta. It follows that the $\mathrm{LO}$ of this species is not suitable for definition of any zonal boundary below Zone NN2. It also follows that the NP25/NN1 boundary must be redefined to provide Zone NP25 with a biostratigraphically meaningful content. The most practical solution would be to propose that Zone NP25 should be defined as the interval between the LO of Sphenolithus distentus and the LO of $S$. ciperoensis, simply because the last event represents perhaps the only nannofossil event around the Oligocene/Miocene boundary that provides consistent biostratigraphic results over wide geographic and latitudinal distances.

\section{The Cyclicargolithus abisectus $\mathrm{LO}$ and the CN1a/CN1b Boundary Problem}

Bukry (1973) used acme occurrences in his zonation, one of which was the termination of the acme (TA) of $C$. abisectus $(\mathrm{CN} 1 \mathrm{a} / \mathrm{CN} 1 \mathrm{~b}$ boundary; Okada and Bukry, 1980). He used this event to subdivide the interval between the LO of $S$. ciperoensis and the FO of $D$. druggii. The $\mathrm{CNla} / \mathrm{CN} 1 \mathrm{~b}$ zonal boundary has been difficult to determine because it is difficult to identify of $C$. abisectus consistently, as discussed by Martini and Müller (1986), and Olafsson (1989), but also because Bukry (1973) never defined his acme occurrence quantitatively. We have followed Olafsson's (1991) taxonomic concept and used a maximum diameter of $11 \mu \mathrm{m}$ to distinguish $C$. abisectus $(>11 \mu \mathrm{m})$ from the smaller Cyclicargolithus floridanus. The large $C$. abisectus morphotypes disappear below the LO of $S$. ciperoensis at Site 807 (Fig. 1). Also, C. abisectus accounts for less than 5\% of the total assemblage toward the end of its range and thus cannot be linked with "abundant" or "acme-like" occurrences. Both these characters imply that Bukry's (1973) acme occurrence cannot be applied in the western equatorial Pacific Ocean, or in the equatorial Indian Ocean (Fornaciari et al., 1990); therefore, Subzone CN1b cannot be defined in these regions.

\section{The Sphenolithus delphix Abundance Interval}

In their study of the equatorial Indian Ocean, Rio et al. (1990) pointed out the occurrence of a short interval of common to abundant $S$. delphix between the LO of S. ciperoensis and the FO of D. druggii, and that this interval could be easily correlated among sites. This $S$. delphix interval is also present in Hole 807A (Fig. 1), in the same
Table 1. Summary of the position of nannofossil events at Hole 807A.

\begin{tabular}{|c|c|c|}
\hline Event & $\begin{array}{l}\text { Core, section, } \\
\text { interval }(\mathrm{cm})\end{array}$ & $\begin{array}{l}\text { Depth } \\
\text { (mbsf) }\end{array}$ \\
\hline T. carinatus LCO & $60 X-3,71 / 60 \times-4,71$ & $566.3-566.3$ \\
\hline S. pseudoheteromorphus FO & $52 X-3,67 / 52 X-4,137$ & $489.5-491.6$ \\
\hline $\begin{array}{l}\text { S. belemnos/S. dissimilis FO } \\
\text { (gradational form) }\end{array}$ & $61 X-2,141 / 61 X-3,71$ & $575.2-576.0$ \\
\hline T. serratus FO & Not reliable & \\
\hline D. druggii FO & $61 X-4,141 / 61 X-5,72$ & $578.2-579.0$ \\
\hline C. fenestratus $\mathrm{O}$ & $63 \mathrm{X}-2,60 / 63 \mathrm{X}-3,71$ & $593.7-595.7$ \\
\hline S. delphix LO & $62 X-5,72 / 62 X-5,141$ & $588.6-589.3$ \\
\hline S. delphix FO & $63 X-3,71 / 63 X-4,74$ & $595.3-596.8$ \\
\hline C. abisectus LO & $66 \mathrm{X}-2,72 / 66 \mathrm{X}-3,73$ & $622.8-624.3$ \\
\hline S. ciperoensis LO & $65 \mathrm{X}-5,71 / 66 \mathrm{X}-1,71$ & $617.7-621.3$ \\
\hline D. bisectus LO & Missing & \\
\hline H. recta LO & Missing & \\
\hline
\end{tabular}

Notes: $\mathrm{LCO}=$ last common occurrence, $\mathrm{FO}=$ first occurrence, and $\mathrm{LO}=$ last occurrence.

stratigraphic position as in the Indian Ocean sites. A restricted range of $S$. delphix has also been reported from the mid-latitude North Atlantic (Miller et al., 1985), with a similar biostratigraphic position to that observed in the equatorial Indian and Pacific Ocean sites. The FO and LO of $S$. delphix probably represent synchronous events between these widely separated regions. Therefore, these two events are suitable for subdividing the 2-m.y.-long interval that separates the LO of S. ciperoensis ( $25.7 \mathrm{Ma}$, according to Olafsson, 1991) from the FO of D. druggii (23.2 Ma, according to Berggren et al., 1985b).

\section{The FO of Discoaster druggii and the Base of Zone NN2 and Subzone CN1c}

Both Martini (1971) and Okada and Bukry (1980) used the FO of D. druggii in their zonal schemes, the former to define the base of Zone NN2 and the latter to define the base of Subzone CN1c. The nominate species is generally a rare component of nannofossil assemblages and often is not continuously present within its range. Bukry (1973) and Olafsson (1989) both suggested that the FO of Triquetrorhabdulus serratus could substitute the FO of $D$. druggii to mark the base of Zone NN2 and/or Subzone CN1c. Discoaster druggii occurs discontinuously and in low abundance at Sites 806 and 807 (Figs. 1 and 3). The lower Miocene interval at Sites 806 and 807 contains extremely rare occurrences of $T$. serratus. In Hole $807 \mathrm{~A}$, the species occurs continuously only well above the FO of D. druggii. The FO of $T$. serratus obviously cannot substitute for the FO of $D$. druggii in definition of the $\mathrm{CN} 1 \mathrm{~b} / \mathrm{CN} 1 \mathrm{c}$ (or NN1/NN2) boundary in the western equatorial Pacific Ocean.

\section{The LO of Triquetrorhabdulus carinatus (NN2/NN3 Boundary)}

Okada and Bukry (1980) used the FO of Sphenolithus belemnos to define the $\mathrm{CN} 1 / \mathrm{CN} 2$ boundary. Martini (1971) indicated a distinct overlap in range between $T$. carinatus and $S$. belemnos. Subsequently it has been established that $T$. carinatus disappears below the FO level of $S$. belemnos, or becomes very rare well below that level (e.g., Parker et al., 1985; Olafsson, 1989, 1991; Fornaciari et al., 1990). The data from Hole 806B (Fig. 3) show that the uppermost consistent and relatively abundant occurrences of $T$. carinatus are located well below the FO of S. belemnos also in the western equatorial Pacific. The LO of $T$. carinatus must be considered a poor marker event, although its drastic decrease in abundance may prove valuable if determined quantitatively and properly mapped biostratigraphically and geographically. From a practical point of view, the best solution to the NN2/NN3 boundary problem would be to change the defining criterion from the LO of T. carinatus to the FO of $S$. belemnos, which has 

(\%) $\quad\left(\mathrm{N} / \mathrm{mm}^{2}\right)$
(\%)
(\%)
(\%)
(\%)
(\%)
(\%)
(\%)
(\%)
(\%)

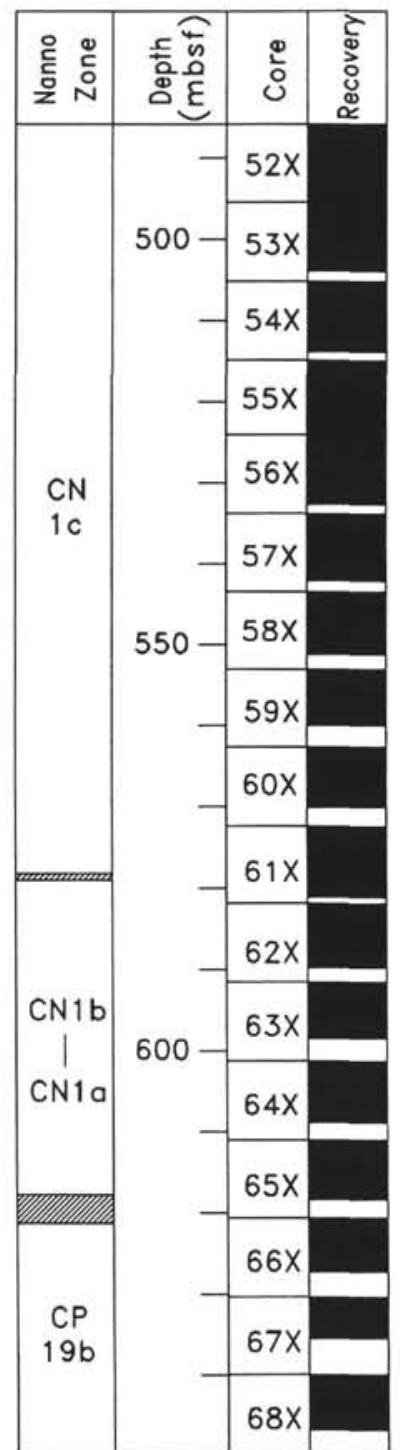
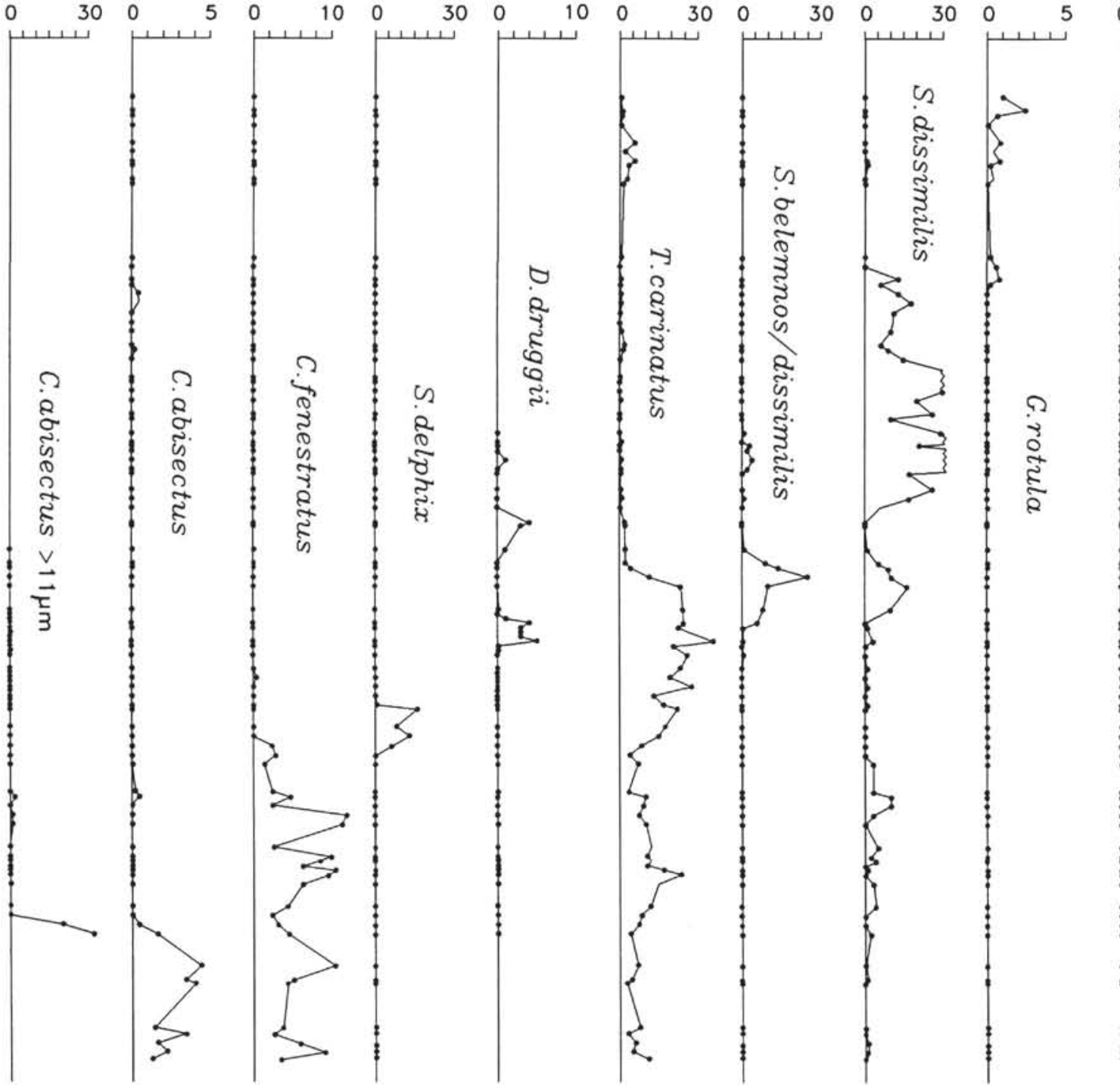

pestion interval from Hole 807A. The nannofossil zone column refer

number indicates that the XCB tool was used. In the recovery column, black represents recovered intervals, whereas white is unrecovered intervals. 


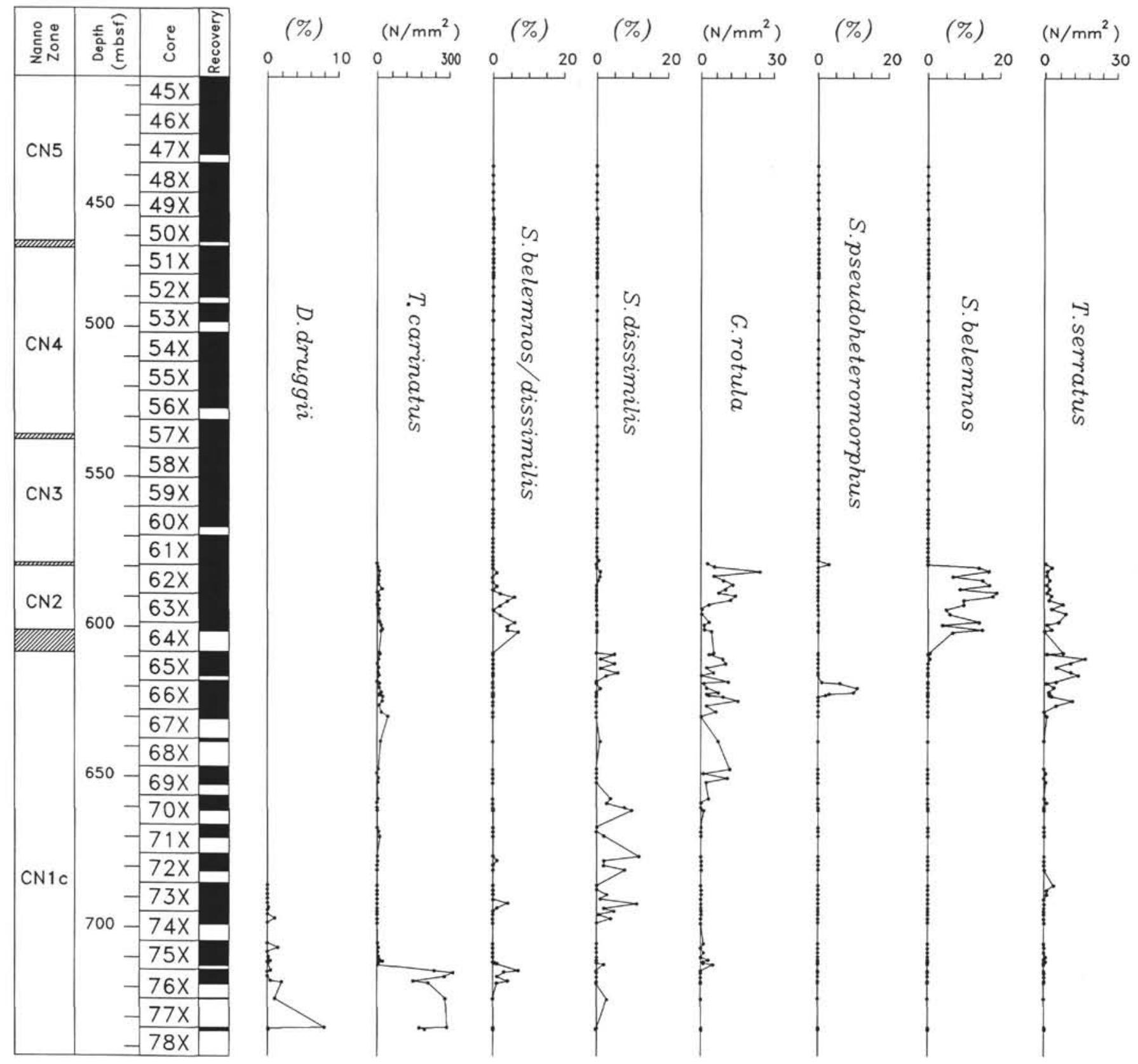

Figure 2. Abundances of $H$. recta from Indian Ocean Hole 714A. The nannofossil zone column refers to Okada and Bukry's (1980) codes. The "X" after a core number indicates that the XCB tool was used. In the recovery column, black represents recovered intervals, whereas white is unrecovered intervals.

been shown to represent a distinct event in many regions, including the Ontong Java Plateau (Fig. 3).

\section{Subdivision of the FO D. druggii/FO S. belemnos Interval (Subzone CN1c)}

Okada and Bukry's (1980) Subzone CN1c represents a long period of time in the early Miocene. The FO of $D$. druggii has been assigned an age of $23.2 \mathrm{Ma}$ (Berggren et al., 1985b) and the FO of S. belemnos an age of about $19.8 \mathrm{Ma}$ (Olafsson, 1991), suggesting a duration of about 3.4 m.y. for Subzone CN1c.

One possible candidate that can be used to subdivide Subzone CN1c is a morphotype that Rio et al. (1990) observed in the equatorial Indian Ocean, and which they described as a gradational form between Sphenolithus dissimilis and S. belemnos. They also suggested that this form appears shortly above the FO of $D$. druggii. Abundance data from Indian Ocean Sites 709 and 710 are shown in Figures 4 and 5. Results from Ontong Java Plateau Sites 806 and 807 are shown in Figures 1 and 3. The data from these four sites indicate that the FO of this gradational sphenolith morphotype falls marginally above the FO of $D$. druggii. Moreover, the abundance pattern of the $S$. dissimilis/S. belemnos morphotype is fairly distinct in three sites, but ambiguous at Site 806.

Another way to subdivide Subzone CN1c is by the FO of Geminilithella rotula. Theodoridis (1984) showed that this species appears within Subzone CN1c. Abundance data from Sites 806 and 807 are shown in Figures 1 and 3, which reveal a poorly developed abundance pattern; it is difficult to pinpoint a distinct FO level.

A third possible candidate is provided by the FO of Sphenolithus pseudoheteromorphus, which Fornaciari et al. (1990) observed 


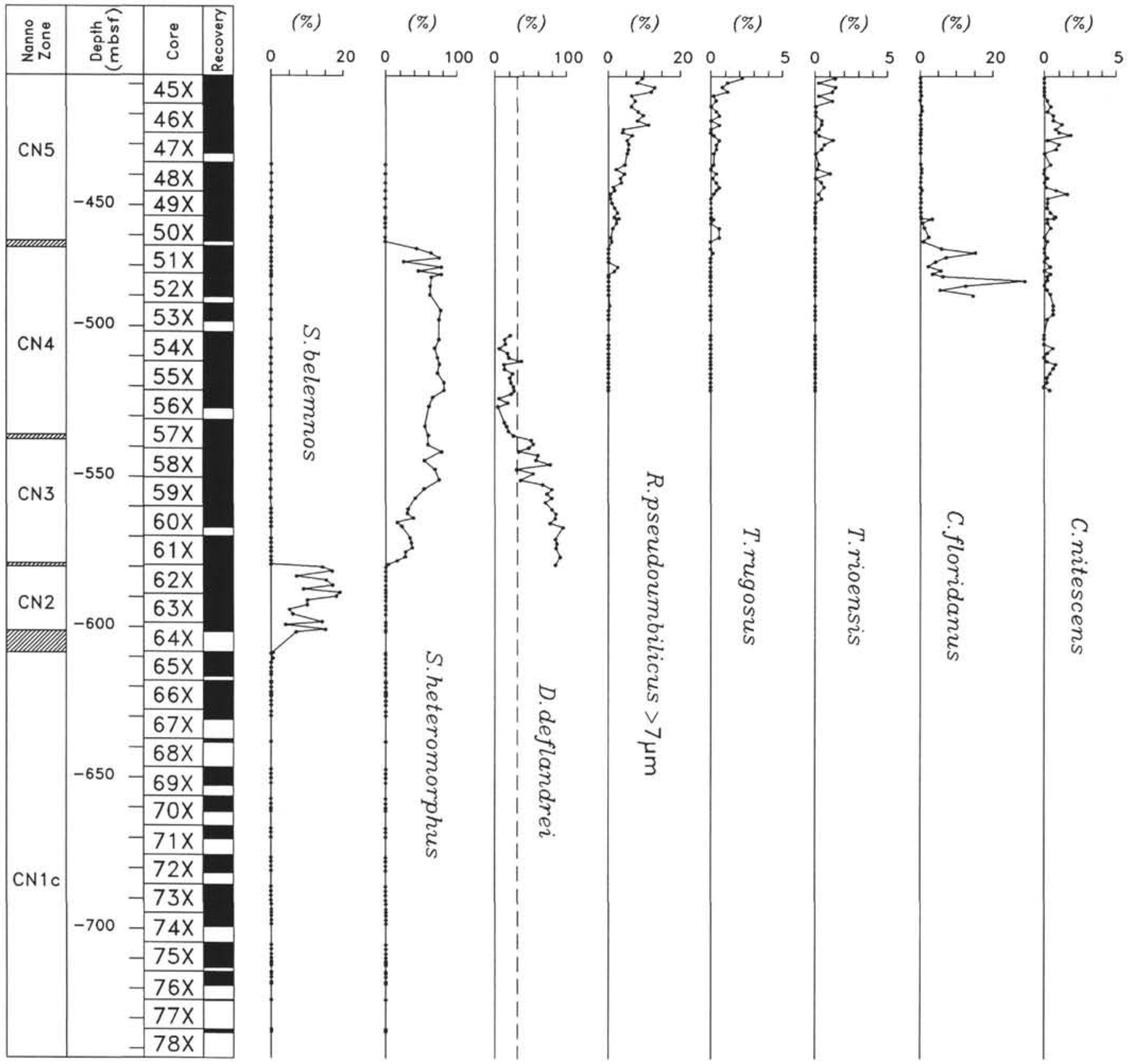

Figure 3. Abundances of nannofossil species from the lower Miocene interval at Hole 806B. The nannofossil zone column refers to Okada and Bukry's (1980) codes. The "X" after a core number indicates that the XCB tool was used. In the recovery column, black represents recovered intervals, whereas white is unrecovered intervals.

shortly below the FO of $S$. belemnos at Indian Ocean Site 714. Abundances of these species are shown from Indian Ocean Site 709 (Fig. 4) and Ontong Java Plateau Site 806 and 807 (Figs. 1 and 3). The FO of Sphenoliths pseudoheteromorphus apparently is a poor candidate for providing a meaningful subdivision of Subzone CN1c (i.e., into two units of approximately similar duration); using the FO of Sphenoliths pseudoheteromorphus rather than the FO of S. belemnos seems to shorten this long subzone by only a few percent. The biostratigraphic interval separating the successive FOs of $D$. druggii and $S$. belemnos, or Subzone $\mathrm{CN} 1 \mathrm{c}$, appears difficult to further subdivide using the available calcareous nannofossil data. The biostratigraphic events discussed here seem to fall close to either the FO of $D$. druggii or the FO of $S$. belemnos, or are associated with ambiguous abundance patterns.

\section{The LO of Sphenolithus belemnos and the FO of Sphenolithus heteromorphus}

Recently collected quantitative data from the equatorial (ODPSite 667) and mid-latitude (DSDP Site 608) Atlantic Ocean, and the tropical Indian Ocean (ODP Site 714) indicate that S. belemnos shows a final sharp decline in abundance immediately below or at the level where $S$. heteromorphus begins an initial sharp rise in abundance (Olafsson, 1989, 1991; Fornaciari et al., 1990). That is, these two species do not overlap, although rare specimens of both species may co-occur in the transition interval.

The abundance plots from Site 806 are shown in Figure 6. Sphenolithus belemnos disappears and $S$. heteromorphus appears over a 1.1-m-long interval (Table 2). If overlapping occurs at Site 806, it has 


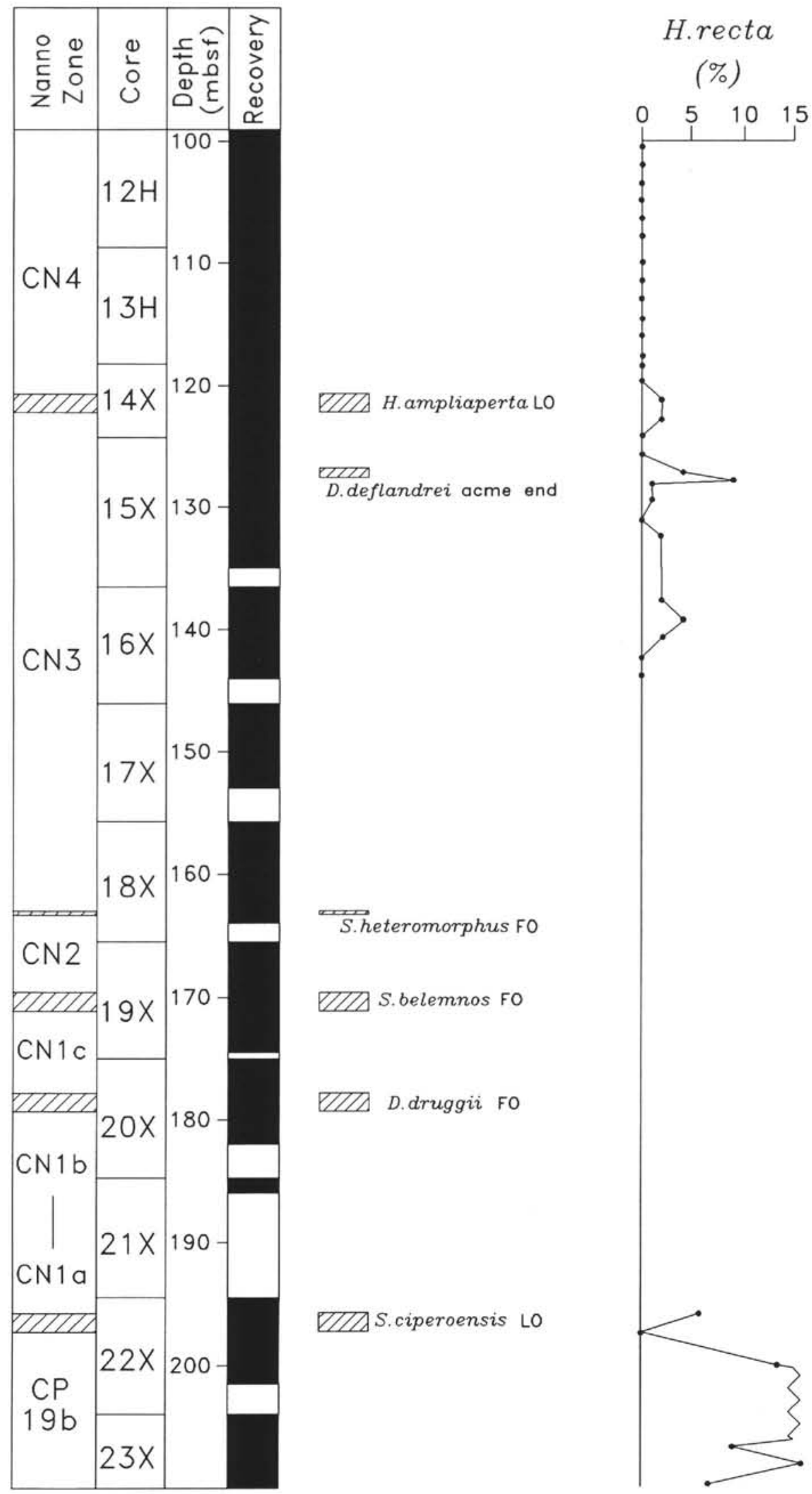

Figure 4. Abundances of Sphenolithus species from the lower Miocene at Indian Ocean Hole 709C. The nannofossil zone column refers to Okada and Bukry's (1980) codes. The " $\mathrm{H}$ " after a core number indicates that the APC tool was used, and the "X" after a core number indicates that the XCB tool was used. In the recovery column, black represents recovered intervals, whereas white is unrecovered intervals. 


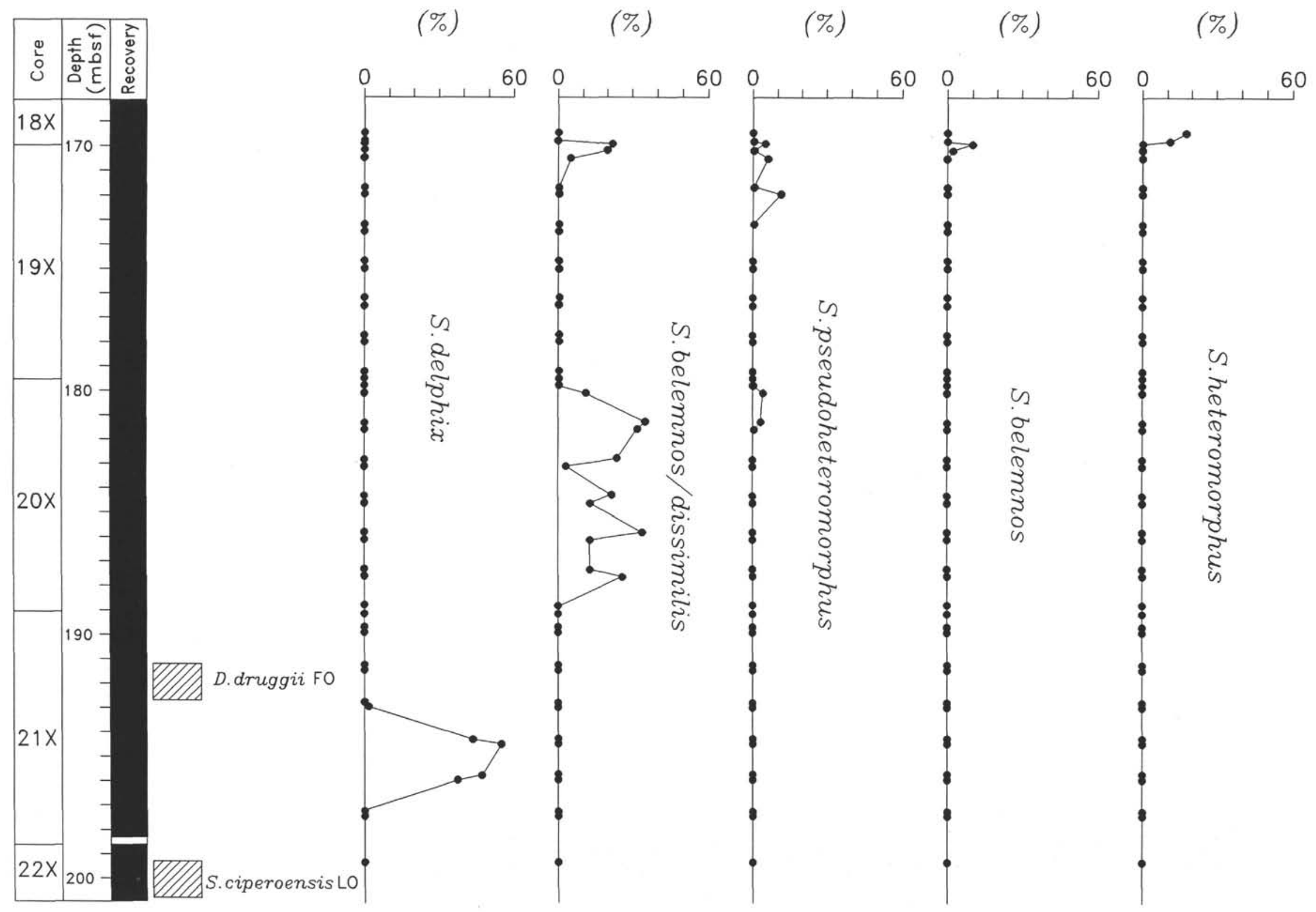

Figure 5. Abundances of Sphenolithus species from the lower Miocene at Indian Ocean Hole 710A. The " $\mathrm{X}$ " after a core number indicates that the XCB tool was used. In the recovery column, black represents recovered intervals, whereas white is unrecovered intervals. 


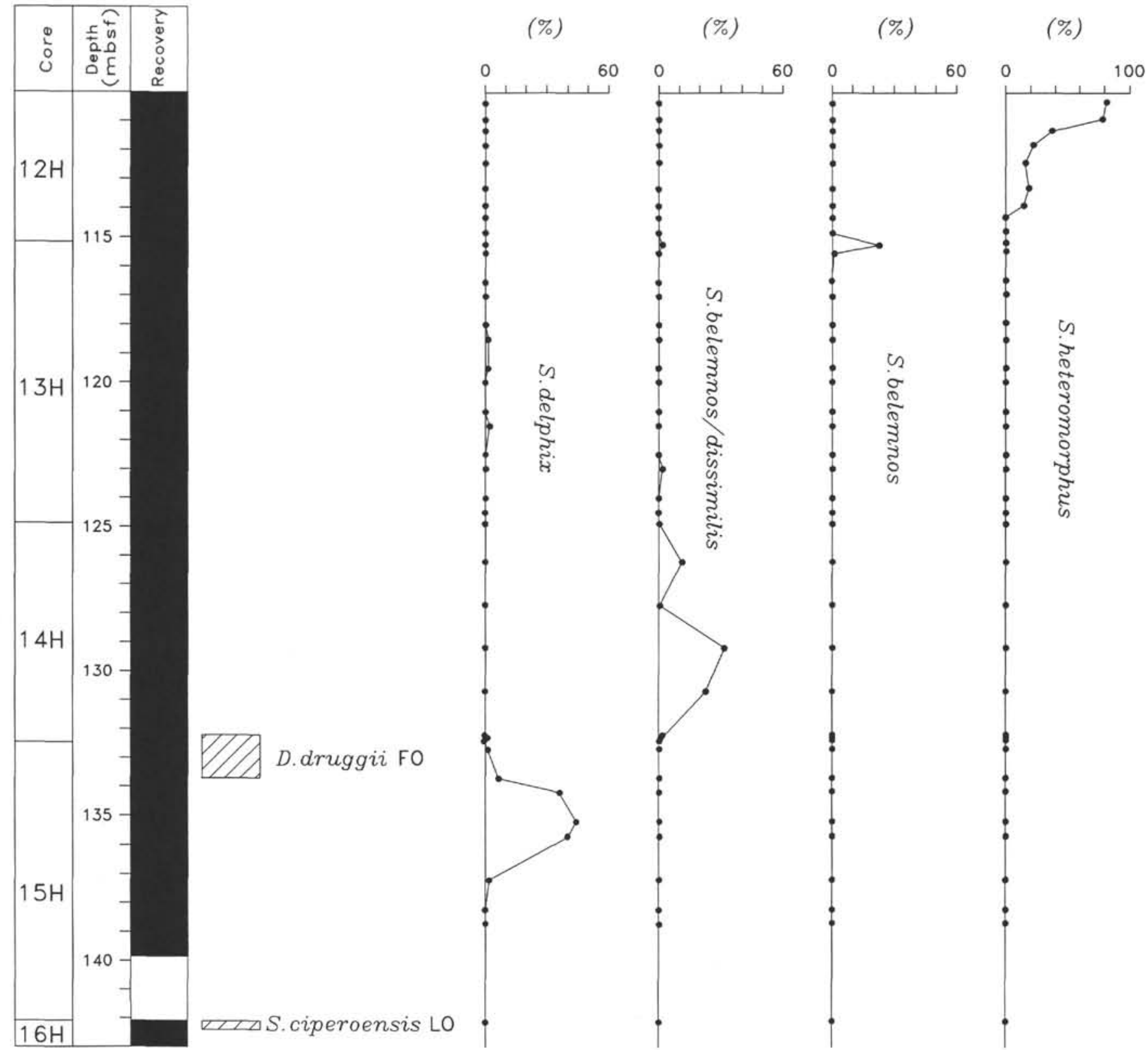

Figure 6. Abundances of nannofossil species from the lower and middle Miocene interval at Hole 806B. The nannofossil zone column refers to Okada and Bukry's (1980) codes. The " $\mathrm{H}$ " after a core number indicates that the APC tool was used. In the recovery column, black represents recovered intervals, whereas white is unrecovered intervals.

to be within that 1.1-m-long unsampled interval. The top of Martini's (1971) Zone NN3 (LO S. belemnos) is therefore closely associated with the top of Okada and Bukry's (1980) Zone CN2 (FO S. heteromorphus). The extinction of $S$. heteromorphus defines the top of Zone NN5 and the top of Zone CN4 in their respective zonal schemes. Backman et al. (1990) demonstrated that the range of S. heteromorphus encompasses a duration of nearly 5 m.y. Both Martini (1971) and Bukry (1973) subdivided that long interval, although most of the criteria they chose for their subdivisions are problematic.

\section{The NN4/NN5 and CN3/CN4 Boundary Problems}

Bramlette and Wilcoxon (1967) described H. ampliaperta and used its extinction to define the top of the $H$. ampliaperta Zone from the Cipero Section on Trinidad. Martini (1971) adopted their definition in his zonal scheme (LO H. ampliaperta defines the top of the
H. ampliaperta Zone, or NN4/NN5 boundary), choosing this event to split the long interval between the LO of $S$. belemnos and the LO of $S$. heteromorphus (although he noted that this species was absent in the western equatorial Pacific). Bukry (1973) also adopted Bramlette and Wilcoxon's (1967) results, although he considered $\mathrm{H}$. ampliaperta only a secondary marker for the top of his $H$. ampliaperta Zone, which he defined primarily by the termination acme (TA) of Discoaster deflandrei. Subsequently, Bukry $(1975,1978)$ favored the FO of Calcidiscus macintyrei as a primary criterion in defining the top of his $H$. ampliaperta Zone, which later was codified as $\mathrm{CN} 3$ by Okada and Bukry (1980). The FO of C. macintyrei was chosen to split the long interval between FO $S$. heteromorphus $(\approx \mathrm{LO} S$. belemnos) and LO S. heteromorphus. In doing so, Bukry also re-ranked the TA of $D$. deflandrei from a previous primary event to a secondary event defining the top of Zone CN3. He had not quantified his acme occurrence of $D$. deflandrei. 
Table 2. Summary of the position of nannofossil events at Hole 806B.

\begin{tabular}{|c|c|c|}
\hline Event & $\begin{array}{l}\text { Core, section, } \\
\text { interval }(\mathrm{cm})\end{array}$ & $\begin{array}{l}\text { Depth } \\
\text { (mbsf) }\end{array}$ \\
\hline D. kugleri FO & Not observed & \\
\hline C. nitescens LO & $45 X-5,50 / 45 X-6,60$ & $423.4-425.0$ \\
\hline C. floridanus LO & $49 \mathrm{X}-7,30 / 50 \mathrm{X}-1,70$ & $464.2-464.3$ \\
\hline S. heteromorphus LO & $50 \mathrm{X}-6,60 / 51 \mathrm{X}-1,60$ & $471.7-474.0$ \\
\hline R. pseudoumbilica $\mathrm{FO}$ & $50 X-3,70 / 50 X-5,70$ & $467.3-470.3$ \\
\hline T. rioensis FO & $49 X-2,60 / 49 X-3,60$ & $457.6-459.0$ \\
\hline T. rugosus FO & $49 \mathrm{X}-1,50 / 49 \mathrm{X}-2,50$ & $456.0-457.6$ \\
\hline H. ampliaperta LO & Not observed & \\
\hline D. deflandrei top acme & $57 X-4,70 / 57 X-5,70$ & $536.0-537.6$ \\
\hline S. heteromorphus FO & $61 X-7,30 / 62 X-1,70$ & $578.9-580.0$ \\
\hline S. belemnos LO & $61 X-7,30 / 62 X-1,70$ & $578.9-580.0$ \\
\hline T. carinatus LCO & $75 \mathrm{X}-6,20 / 76 \mathrm{X}-1,20$ & $712.2-714.3$ \\
\hline S. belemnos FO & $64 X-2,119 / 65 X-1,20$ & $601.3-608.5$ \\
\hline S. pseudoheteromorphus FO & $66 \mathrm{X}-4,19 / 66 \mathrm{X}-4,69$ & $622.6-623.1$ \\
\hline $\begin{array}{l}\text { S. belemnos/S. dissimilis FO } \\
\text { (gradational form) }\end{array}$ & 76X-CC $776 \mathrm{X}-3,119$ & $723.7-718.3$ \\
\hline T. serratus FO & Not reliable & \\
\hline D. druggii FO & $77 \mathrm{X}-\mathrm{CC} / 78 \mathrm{X}-1,18$ & $733.4-733.8$ \\
\hline
\end{tabular}

Notes: $\mathrm{LCO}=$ last common occurrence, $\mathrm{FO}=$ first occurrence, and $\mathrm{LO}=$ last occurrence.

Helicosphaera ampliaperta has not been observed in any site drilled during Leg 130, which is consistent with Martini's (1971) observation, and implies that the NN4/NN5 boundary cannot be recognized in the Ontong Java Plateau region. From DSDP Site 608 located in the mid-latitude North Atlantic, Olafsson (1991) demonstrated that $H$. ampliaperta provides a relatively distinct event that splits the long NN4/NN5 zonal interval into two halves of approximately equal duration. Thus, the LO of this species may be biostratigraphically valuable on a regional scale. On the other hand, the paleoecological exclusion of $H$. ampliaperta from vast areas in openocean environments severely decreases the biostratigraphic resolution in Martini's (1971) Miocene zonal scheme.

Rio et al. (1990) quantified the abundance of $D$. deflandrei and emphasized the importance of the TA of $D$. deflandrei for subdividing of the long stratigraphic interval defined by the total range of $S$. heteromorphus (Zone CN4). They suggested that this acme event could be defined as a shift in abundance from above $30 \%$ to below $30 \%$ of $D$. deflandrei, relative to the total Discoaster assemblage. Such a shift in general abundance is clearly present at Site 806 (Fig. 6). The biostratigraphic position of this event at Site 806, nearly halfway into the life range of $S$. heteromorphus, is in agreement with the results from the Indian Ocean sites. The change in abundance of $D$. deflandrei relative to other discoasters may be the best marker for subdividing the long interval represented by the range of $S$. heteromorphus.

\section{The FO of Reticulofenestra pseudoumbilica}

The taxonomy at the species level within the genus Reticulofenestra is ambiguous, partly because working definitions of species may involve a variety of placolith sizes. The consequence is widely differing biostratigraphic assignments of, for example, the FO level of $R$. pseudoumbilica, as discussed by Fornaciari et al. (1990). These authors applied a lower size limit of $7 \mu \mathrm{m}$ to define $R$. pseudoumbilica and accordingly its FO is correlated to the top of Zone CN4, just below the LO of S. heteromorphus at ODP Site 714 (Maldives, Indian Ocean). The stratigraphic occurrences of early forms of large $R$. pseudoumbilica from Site 806 is shown in Figure 6. The FO of $R$. pseudoumbilica in this site correlates to the very top of Zone CN4. In the mid-latitude North Atlantic Site 608, however, this event clearly is above the LO of $S$. heteromorphus (Olafsson, 1991). As identical definitions were adopted in these studies from Sites 608, 714, and 806 , one can conclude that $R$. pseudoumbilica (larger than $7 \mu \mathrm{m}$ ) appears later in mid-latitudes than in tropical/equatorial regions.

\section{The FOs of Triquetrorhabdulus rugosus and Triquetrorhabdulus rioensis}

Triquetrorhabdulus rugosus and T. rioensis have their FOs slightly above the FO level of $R$. pseudoumbilica and hence also above the FO of $S$. heteromorphus (Fig. 6). This particular sequence of biostratigraphic events has also been observed in the central equatorial Pacific Ocean, the equatorial Indian and Atlantic Oceans, and the mid-latitude North Atlantic (Olafsson, 1989, 1991; Fornaciari et al., 1990). These triquetrorhabdulid species are seldom common or abundant members of the nannofossil assemblages, although their distinctive appearance makes them easy to recognize in the light microscope. This, together with the consistency in their FOs in relation to neighboring nannofossil events confirms their biostratigraphic usefulness.

\section{The Subdivision of Zone CN5 (NN5/NN6)}

The FO of Discoaster kugleri was used as the original definition of the NN6/NN7 and CN5a/CN5b zonal boundaries. This event, however, is difficult to determine (Bukry, 1973; Perch-Nielsen, 1985; Gartner and Chow, 1985; Rio et al., 1990), partly because D. kugleri is difficult to recognize in overgrown assemblages and partly because this species is rare or absent in many middle Miocene sections. Alternative criteria, therefore, have been proposed for subdividing the interval between the LO of S. heteromorphus and the FO of Catinaster coalithus, corresponding to Zone CN5 (Okada and Bukry, 1980) or Zones NN6 and NN7 (Martini, 1971). Among the alternative events has been the LO of Cyclicargolithus floridanus (Bukry, 1973) and the LO of Coronocyclus nitescens (Gartner and Chow, 1985; Fornaciari et al., 1990). The abundances of these two species are plotted from Site 806 (Fig. 6).

Cyclicargolithus floridanus disappears shortly after the LO of S. heteromorphus in the western equatorial Pacific Ocean (Fig. 6), as it does in the equatorial Atlantic and Indian oceans and in the central equatorial Pacific Ocean (Olafsson, 1989; Fornaciari et al., 1990). At the mid-latitude North Atlantic Site 608, however, Olafsson (1991) observed a marked decrease in the abundance of $C$. floridanus close to the LO of $S$. heteromorphus, but the former species survived the latter by some 2 m.y. In the absence of reworking, this suggests that C. floridanus varies latitudinally and should be used with caution for long-distance correlation.

Coronocyclus nitescens apparently becomes extinct in the upper part of the section at Site 806 (Fig. 6) in a biostratigraphically similar position as has been previously observed from the tropical Indian Ocean (midway between the LO $S$. heteromorphus and the FO $C$. coalithus, Fornaciari et al., 1990). Thus, this event appears useful for correlating low-latitude oceanic sediments.

\section{CONCLUSIONS}

Quantitative distribution patterns of selected calcareous nannofossil species have been determined from lower and middle Miocene sediments cored from the Ontong Java Plateau in the western equatorial Pacific Ocean. Apart from establishing biostratigraphic correlations between Sites 806 and 807 , our goal has been to improve the existing quantitative data base established previously from DSDP and ODP sites in the equatorial Indian Ocean (Fornaciari et al., 1990), the equatorial and mid-latitude Atlantic Ocean (Olafsson, 1989, 1991), and the central equatorial Pacific Ocean (Olafsson, 1989). In turn, this data base help to improve lower and middle Miocene nannofossil biostratigraphic resolution and to improve our knowledge of the degree of reliability of the different marker events. The sharpness of events is one critical factor in the evaluation of the reliability. The degree of synchrony over geographic distance is another critical factor. Correlations between Sites 806 and 807 on the one hand, and Indian Ocean sites on the other, are shown in Figure 7. 


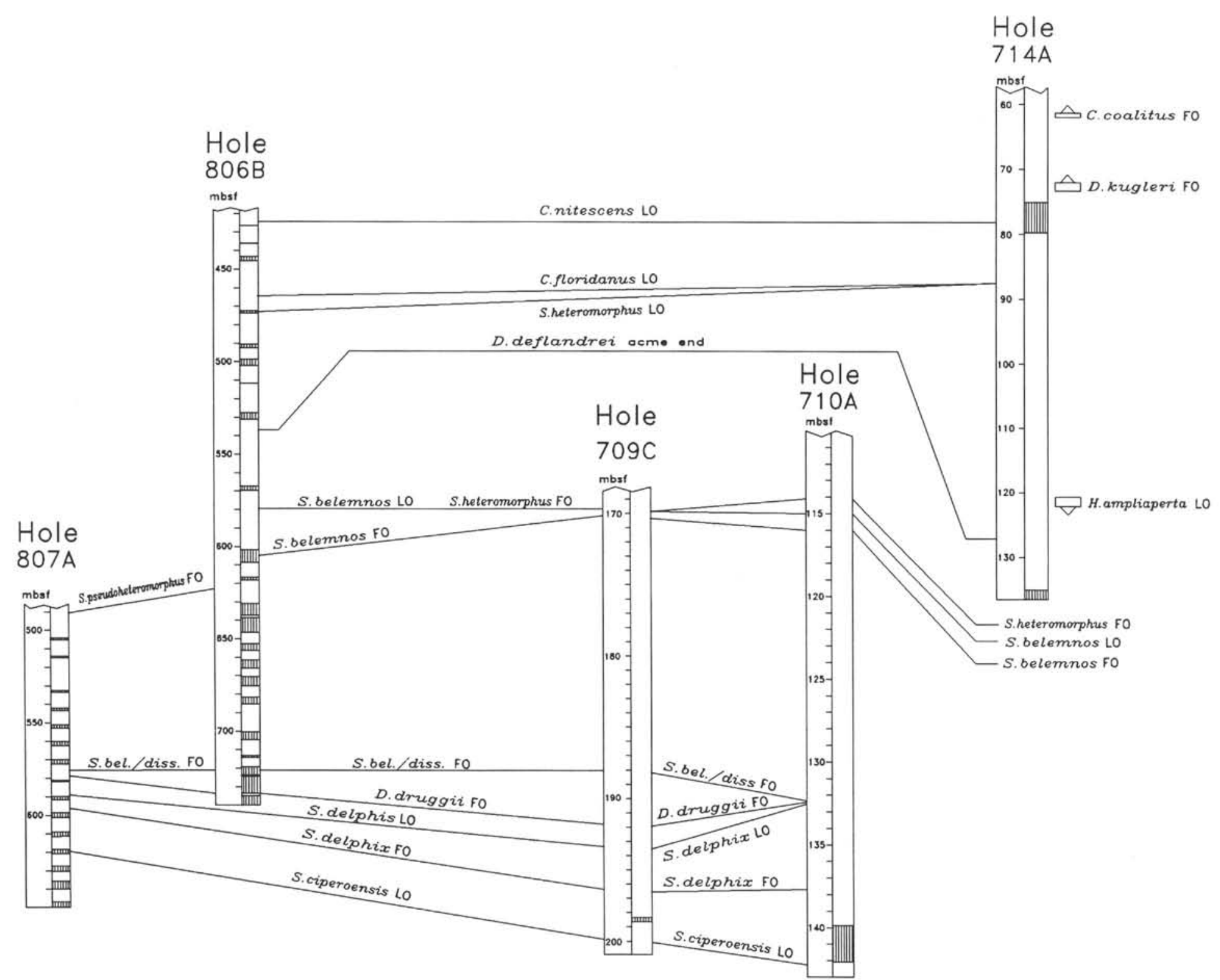


The following conclusions seem warranted by the available data:

1. The LO of $H$. recta is not suitable for defining the top of Zone NP25 because this species is missing in most open-ocean sediments and, when present, becomes extinct after the FO of D. druggii. Thus, the NP25/NN1 zonal boundary is hard to define.

2 . The LO of $S$. ciperoensis is considered to be the only event around the Oligocene/Miocene boundary that provides consistent biostratigraphic information over wide geographic distances.

3 . The most practical solution to the NP25/NN1 boundary problem would be to redefine the top of Zone NP25 and to use the LO of $S$. ciperoensis rather than the $\mathrm{LO}$ of $H$. recta.

4. Dictyococcites bisectus is rare or missing in low-latitude sediments. Thus, this species disappears earlier in low-latitude environments than in mid- to high-latitude regions and should not be used as an auxiliary marker for the CP19/CN1 zonal boundary. The LO of this species probably can, however, be used for regional correlation, particularly in mid- to high-latitude regions.

5. Counts and morphometric investigations of $C$. abisectus suggest that Bukry's (1973) acme occurrence cannot be applied either in the western equatorial Pacific Ocean or the equatorial Indian Ocean, implying that Subzone CN1b cannot be defined in these regions.

6. Sphenolithus delphix is restricted to the interval between the LO of $S$. ciperoensis and the FO of $D$. druggii. Within that biostratigraphic interval, this species is common in the equatorial Indian Ocean, the mid- and high-latitude Atlantic Ocean, the western equatorial Pacific Ocean and the Mediterranean Sea. Both the FO and LO of S. delphix are useful events for subdividing the above-mentioned biostratigraphic interval (having a duration of about 2 m.y.).

7. The LO of T. carinatus, which defines the top of Zone NN2, must be considered as a poor marker event because of its low abundances and inconsistent occurrences toward the end of its range.

8. The long Subzone CN1c (3.4 m.y.), between the FO of $D$. druggii and the FO of $S$. belemnos, is difficult to subdivide. One possible candidate is a gradational form between $S$. dissimilis and $S$. belemnos.

9. Sphenolithus belemnos shows an initial sharp decline in abundance immediately below or at the level where $S$. heteromorphus shows a sharp rise in abundance, a pattern observed from the equatorial Atlantic, Indian, and Pacific oceans, as well as in the mid-latitude North Atlantic.

10. The termination of the acme of $D$. deflandrei, decreasing to $<30 \%$ of the total discoaster assemblage, appears to be the best marker for the $\mathrm{CN} 3 / \mathrm{CN} 4$ (NN4/NN5) zonal boundary; $H$. ampliaperta is missing in most oceanic sediments and $C$. macintyrei is associated with taxonomic ambiguities in the early part of its range.

11. The FOs of $R$. pseudoumbilica $(>7 \mu \mathrm{m}), T$. rugosus, and $T$. rioensis occur close to the $\mathrm{LO}$ of $S$. heteromorphus in the equatorial Indian and Pacific oceans; the first of these events, however, occurs later in the mid-latitude North Atlantic than in low-latitude environments. The two latter species have low abundances in the early part of their ranges, but they are taxonomically distinctive and appear useful for biostratigraphic correlation at least in low-latitude regions.

12. Cyclicargolithus floridanus disappears shortly above $S$. heteromorphus in low-latitude regions, but survives this species for a considerably longer interval (representing about 2 m.y.) in the midlatitude North Atlantic. Thus, the LO of C. floridanus is variable and can probably be used only on a regional scale as an auxiliary marker for defining the $\mathrm{CN} 5 \mathrm{a} / \mathrm{CN} 5 \mathrm{~b}$ subzonal boundary.

13. The value of the LO of $C$. nitescens as a biostratigraphic marker event appears restricted to lower latitude environments because of its low and inconsistent abundances at mid-latitudes.

\section{ACKNOWLEDGMENTS}

We thank the Ocean Drilling Program for making the samples available for this project. We are grateful to our ODP publications coordinator, Gigi Delgado; to our ODP editor, Eva M. Maddox; and to the two reviewers, Tim Bralower and Stefan Gartner. Their comments improved the manuscript. Financial support was provided by Centro CNR per L'Orogeno delle Alpi Orientali (Padova University), and by the University of Stockholm.

\section{REFERENCES}

Backman, J., Duncan, R.A., et al., 1988. Proc. ODP, Init. Repts., 115: College Station, TX (Ocean Drilling Program).

Backman, J., Schneider, D.A., Rio, D., and Okada, H., 1990. Neogene lowlatitude magnetostratigraphy from Site 710 and revised age estimates of Miocene nannofossil events. In Duncan, R.A., Backman, J., Peterson, L.C., et al., Proc. ODP, Sci. Results, 115: College Station, TX (Ocean Drilling Program), 271-276.

Backman, J., and Shackleton, N.J., 1983. Quantitative biochronology of Pliocene and Pleistocene calcareous nannofossils from the Atlantic, Indian and Pacific ocean. Mar. Micropaleontol., 8:141-170.

Berggren, W.A., Kent, D.V., and Flynn, J.J., 1985. Jurassic to Paleogene: Part 2. Paleogene geochronology and chronostratigraphy. In Snelling, N.J. (Ed.), The Chronology of the Geological Record. Mem.-Geol. Soc. London, 10:141-195.

Berggren, W.A., Kent, D.V., and Van Couvering, J.A., 1985. The Neogene: Part 2. Neogene geochronology and chronostratigraphy. In Snelling, N.J. (Ed.), The Chronology of the Geological Record. Mem.-Geol. Soc. Mem., 10:211-260.

Bizon, G., and Müller, C., 1979. Remarks on the Oligocene/Miocene boundary based on the results obtained from the Pacific and Indian oceans. VII Int. Congr. Medit. Neogene, Ann. Geol. Pays Hellen., 1:101-111.

Bramlette, M.N., and Wilcoxon, J.A., 1967. Middle Tertiary calcareous nannoplankton of the Cipero Section, Trinidad, B.W.I. Tulane Stud. Geol. Paleontol., 5:93-132.

Bukry, D., 1973. Low-latitude coccolith biostratigraphic zonation. In Edgard, N.T., Saunders, J.B., et al., Init. Repts. DSDP, 15: Washington (U.S. Govt. Printing Office), 685-703.

1975. Coccolith and silicoflagellate stratigraphy, Northwestern Pacific Ocean, Deep Sea Drilling Project Leg 32. In Larson, R.L., Moberly, R., et al., Init. Repts. DSDP, 32: Washington (U.S. Govt. Printing Office), 677-701.

, 1978. Biostratigraphy of Cenozoic marine sediment by calcareous nannofossils. Micropaleontology, 24:44-60.

Fornaciari, E., Raffi, I., Rio, D., Villa, G., Backman, J., and Olafsson, G., 1990. Quantitative distribution patterns of Oligocene and Miocene calcareous nannofossils from western equatorial Indian Ocean. In Duncan, R.A., Backman, J., Peterson, L.C., et al., Proc. ODP, Sci. Results, 115: College Station, TX (Ocean Drilling Program), 237-254.

Gartner, S., and Chow, J., 1985. Calcareous nannofossil biostratigraphy, Deep Sea Drilling Project Leg 85, eastern equatorial Pacific. In Mayer, L., Theyer, F., Thomas, E., et al., Init. Repts, DSDP, 85: Washington (U.S. Govt. Printing Office), 609-619.

Kroenke, L.W., Berger, W.H., Janacek, T.R., et al., 1990. Proc. ODP, Init. Repts., 130: College Station, TX (Ocean Drilling Program).

Martini, E., 1971. Standard Tertiary and Quaternary calcareous nannoplankton zonation. In Farinacci, A. (Ed.), Proc. 2nd Planktonic Conf. Roma: Rome (Ed. Tecnosci.), 2:739-785.

Martini, E., and Müller, C., 1986. Current Tertiary and Quaternary calcareous nannoplankton stratigraphy and correlation. Newsl. Stratigr., 16:99-112.

Miller, K.G., Aubry, M.-P., Khan, K.J., Melillo, A.J., Kent, D.V., and Berggren, W.A., 1985. Oligocene-Miocene biostratigraphy, magnetostratigraphy and isotopic stratigraphy of the Western North Atlantic. Geology, 13:257-261.

Okada, H., and Bukry, D., 1980. Supplementary modification and introduction of code numbers to the low-latitude coccolith biostratigraphic zonation (Bukry, 1973; 1975). Mar. Micropaleontol., 5:321-325.

Olafsson, G., 1989. Quantitative calcareous nannofossil biostratigraphy of upper Oligocene to middle Miocene sediment from ODP Hole 667 A and middle Miocene sediment from DSDP Site 574. In Ruddiman, W., Sarnthein, M., Baldauf, J., et al., Proc. ODP, Sci. Results, 108: College Station, TX (Ocean Drilling Program), 9-22.

1991. Quantitative calcareous nannofossil biostratigraphy and biochronology of early through late Miocene sediments from DSDP Hole 608. Mar. Micropaleontol.

Parker, M.E., Clark, M., and Wise, S.W., Jr., 1985. Calcareous nannofossils of Deep Sea Drilling Project Sites 558 and 563, North Atlantic Ocean: biostratigraphy and the distribution of Braarudosphaerids. In Bougault, H., Cande, S.C., et al., Init. Repts. DSDP, 82: Washington (U.S. Govt. Printing Office), 559-589. 
Perch-Nielsen, K., 1985. Cenozoic calcareous nannofossils. In Bolli, H.M., Saunders, J.B., and Perch-Nielsen, K. (Eds.), Plankton Stratigraphy: Cambridge (Cambridge Univ. Press), 427-554.

Rio, D., Fornaciari, E., and Olafsson, G., 1991. New Miocene calcareous nannofossil species from the tropical Indian Ocean. Mem. Sci. Geol. (Padova).

Rio, D., Fornaciari, E., and Raffi, I., 1990. Late Oligocene through early Pleistocene calcareous nannofossils from western equatorial Indian Ocean (Leg 115). In Duncan, R.A., Backman, J., Peterson, L.C., et al., Proc. ODP, Sci. Results, 115: College Station, TX (Ocean Drilling Program), 175-235.

Rio, D., Raffi, I., and Villa, G., 1990. Pliocene-Pleistocene calcareous nannofossil distribution patterns in the western Mediterranean. $\ln$ Kastens, K.A., Mascle, J., et al., Proc. ODP, Sci. Results, 107: College Station, TX (Ocean Drilling Program), 513-533.
Theodoridis, S., 1984. Calcareous nannofossil biozonation of the Miocene and revision of the helicoliths and discoasters. Utrecht Micropaleontol. Bull., $32: 1-271$.

Wei, W., and Wise, S.W., Jr., 1989. Paleogene calcareous nannofossil biochronology: results from South Atlantic Site 516. Mar. Micropaleontol., 14:119-152.

Date of initial receipt: 22 October 1991

Date of acceptance: 17 May 1992

Ms 130B-009 